\title{
Cigarette Butt Disposal Behavior: A Case Study of a Public Beach on Jekyll Island, Georgia, USA
}

\author{
Maranda R. Miller ${ }^{1} \&$ Mark E. Burbach ${ }^{2}$ \\ ${ }^{1}$ School of Natural Resources, University of Nebraska-Lincoln, USA \\ ${ }^{2}$ Conservation and Survey Division, School of Natural Resources, University of Nebraska-Lincoln, USA \\ Correspondence: Mark E. Burbach, Conservation and Survey Division, School of Natural Resources, University \\ of Nebraska-Lincoln, Lincoln, NE, 68583-0996, USA. Tel: 1-402-472-8210. E-mail: mburbach1@unl.edu
}

Received: May 26, 2020

Accepted: August 29, 2020

Online Published: September 30, 2020

doi:10.5539/enrr.v10n3p27

URL: https://doi.org/10.5539/enrr.v10n3p27

\begin{abstract}
Improperly discarded cigarette butts are a substantial environmental problem. This study explored factors influencing cigarette butt discarding behavior on a public beach on Jekyll Island, Georgia, USA. A mixed-mode design utilized quantitative and qualitative data to study improper cigarette butt disposal. We surveyed smokers regarding their place attachment, environmental attitudes, environmental awareness, and habit as predictors of improper cigarette butt disposal. Environmental attitudes, environmental awareness, and habits were significant predictors of improper cigarette butt disposal behavior. A qualitative inquiry further explored the phenomenon of cigarette butt disposal from the smokers' perspectives. Interviews illustrated that "improper disposers" experienced themes involving uncertainty that cigarette butts are litter, a lack of knowledge, problems with cigarette butt receptacles currently in place, the requirement of a conscious choice about how and where to discard a butt, and statements that contradicted the behavior observed. Themes that emerged from interviews with "proper disposers" included cigarette butts are clearly litter, awareness of social constructs that disapprove of smokers and their behavior, awareness of the cumulative effects of cigarette butts on the beach, minimal obstacles to discarding properly, and feelings of personal responsibility. Implications of the study results are discussed.
\end{abstract}

Keywords: Cigarette butt disposal, environmental behavior, environmental attitudes, environmental awareness, habits

\section{Introduction}

\subsection{Introduction to the Problem}

Cigarette butts are some of the most commonly found trash on beaches worldwide (Addamo, Laroche, \& Hanke, 2017; Ocean Conservancy, 2019). Cigarette butts cause problems when they are improperly discarded into the environment for several reasons. Most filters in cigarette butts (97\%) (Solvay, 2016) are made of cellulose acetate (plasticized fibers) and do not break down in the environment (Novotny, Lum, Smith, Wang, \& Barnes, 2009; Puls Wilson, \& Hölter, 2011; Robertson, Thomas, Suthar, \& Brown, 2012). Cigarette butts contain toxic chemicals that leech into the environment including arsenic, polyaromatic hydrocarbons (PAHs), and heavy metals (Moriwaki, Kitajima, \& Katahira, 2009). Moerman and Potts (2011) examined metals that leached from smoked cigarette litter and discovered that 11 of the 12 metals tested were found in quantifiable amounts (Moerman \& Potts, 2011). Micevska, Warne, Pablo, and Patra (2006) found cigarette butt leachates nicotine and ethylphenol in Ceriodaphnia cf. dubia (freshwater water flea) and Vibrio fischeri (tropical and sub-tropical water bacteria). A study of 34 green sea turtles (Chelonia mydas) that stranded on a beach in southern Brazil found cigarette butts among the debris in the turtles' gastrointestinal systems (Tourinho, do Sul, \& Fillmann, 2010). Cigarette butt leachates also pose a hazard to human health (Novotny et al., 2011).

In addition to environmental concerns, litter on the beach has the potential to adversely affect tourism. Beach tourists often note the cleanliness of the beach as a major factor in the satisfaction of their visit and likelihood to revisit (Dodds \& Holmes, 2019; Vaz, Williams, Pereira, \& Phillips, 2009). Tudor and Williams (2003) found that cigarette butts ranked in the top 20 most offensive items to tourists at eight beaches in the United Kingdom. 


\subsection{Cigarette Butts on Jekyll Island}

Jekyll Island is a 7-mile long barrier island off the coast of southern Georgia. The island is managed for the conservation of natural resources as well as family-friendly tourism activities. According to the Master Plan of the Jekyll Island Authority, "Jekyll Island is a unique, state-owned barrier island that balances conserving and preserving natural, historic, and cultural resources with providing accessible, affordable recreation, vacation, and education opportunities for the people of Georgia and beyond" (Jekyll Island Authority, 2014, p. 4). Approximately 1 million people visit the island annually (Jekyll Island Authority, 2015). Because of this, the island's economy relies heavily on tourism.

The Georgia Sea Turtle Center on Jekyll Island established a marine debris collection project in 2007. The project collected over 14,250 cigarette butts from the beaches between 2012 and 2015 (University of Georgia, 2016; Green, 2018). Cigarette butts made up $36 \%$ of the plastic debris. The purpose of this study was to investigate factors that influence cigarette butt disposal behavior on Jekyll Island.

\subsection{Literature Review}

Littering behavior has been studied from the perspective of inconsistent law enforcement (Schultz \& Oleen, 2014), social norms (Cialdini, Reno, \& Kallgren, 1990; Schultz \& Stein, 2009), disposal receptacle convenience and design (Bagley, Salazar, \& Wetmore, 2012; Schultz, Bator, Large, Bruni, \& Tabanico, 2013; Schultz \& Stein, 2009), intentions (Schultz et al., 2013), and awareness of consequences (Nugent, 2013; Rath, Rubenstein, Curry, Shank, \& Cartwright, 2012). With the exception of Schultz et al. (2013), these studies did not involve cigarette butt disposal and none specifically involved disposal on beaches.

A person's attachment to a place may affect an individual's cigarette butt disposal behavior. Place attachment is frequently associated with environmentally responsible behavior (e.g. Hines, Hungerford, \& Tomera, 1987; Relph, 1976; Tuan, 1974, 1975; Vaske \& Kobrin, 2001). A popular current description of place attachment is that it is "an emotional bond between a person and a particular place" (Williams \& Vaske, 2003, p. 838). It often takes into account the "intensity of the bond that people have with places and environments" (Floress, Akamani, Halvorsen, Kozich, \& Davenport, 2015, p. 86). Importantly, place attachment often occurs "in an individual whose positivelyvalenced knowledge of the environment in question largely exceeds the negatively-valenced knowledge" (Giuliani, 2003, p. 151).

Place attachment has been studied extensively in recreational settings, national parks, and private land management; and primarily focuses on attempts to promote pro-environmental behavior in such settings (Hernandez, Martín, Ruiz, \& Hidalgo. 2010; Jorgensen \& Stedman, 2001; Kyle, Absher, \& Graefe, 2003; Kyle, Graefe, Manning, \& Bacon 2004; Ramkissoon \& Mavondo, 2014; Ramkissoon, Weiler, \& Graham, 2012; Raymond, Brown, \& Weber, 2010; Tonge, Ryan, Moore, \& Beckley, 2014). Jorgensen and Stedman (2001) found that lakeside property owners who had high place attachment were more willing to perform actions that protected the lake than those with lower place attachment. Williams and Vaske (2003) found that "people develop different levels and forms of attachment to different places (p. 838)", including natural landscapes. This idea is extrapolated to smokers to form the first hypothesis:

H1: Smokers who improperly dispose of cigarette butts on a public beach have a significantly lower level of

place attachment to that area than smokers who properly dispose of cigarette butts on a public beach.

A second factor that may affect cigarette butt disposal behavior is environmental attitudes. An attitude is defined as "a psychological tendency that is expressed by evaluating a particular entity with some degree of favor or disfavor" (Eagly \& Chaiken, 1993, p.1). Environmental attitudes can account for how we relate to nature and our surroundings (Pam, 2013).

The theory of planned behavior contributes to our understanding of how environmental attitudes can predict ecological behavior. This theory states that behavior is guided, in part, by one's attitude toward a specific behavior. These attitudes influence a person's intentions. These intentions then join with a person's perceptions of their behavioral control to influence the actual behavior they perform (Ajzen, 1991). Therefore, environmental attitudes are important to understand in relation to cigarette butt disposal behavior because they allow us to partially predict an individual's disposal behavior based on the attitudes they have towards that environment. For this reason, Newhouse (1990) states that environmental attitudes present promising ways to guide behavior in a more positive ecological direction.

Environmental attitudes have been found to influence recycling, green purchasing/consumer action, and energy consumption behaviors (Balderjahn, 1988; Diekmann \& Preisendörfer, 2003; Grunert \& Juhl, 1995; Lin \& Huang, 
2012; Sapci \& Considine, 2014; Tseng \& Hung, 2013; Vining \& Ebreo, 1992). This research supports the following hypothesis:

H2: Smokers who improperly dispose of cigarette butts on a public beach have significantly lower proenvironmental attitudes than smokers who properly dispose of cigarette butts on a public beach.

A third factor that may affect an individual's cigarette but disposal behavior is environmental awareness, otherwise known as awareness of environmental consequences, or "knowing of the impact of human behavior on the environment" (Kollmuss \& Agyeman, 2002, p. 253). An individual must understand that their personal behavior has consequences in order to affect their behavior. This idea stems from two inter-related theories. The first, the value-belief-norm theory, states that an individual's "intentions to perform pro-environmental behaviors include an awareness of the consequences" of their actions (Hansla, Gamble, Juliusson, \& Gärling, 2008, p. 1). This means that the individual recognizes there are adverse environmental problems as a consequence of their behavior. This awareness of consequences can in turn cause an individual to develop a personal or moral norm that subsequently guides their behavior to be more pro-environmental, as illustrated in the norm-activation theory of altruistic behavior (Schwartz, 1977).

Many studies have found awareness of consequences to be a predictor of general pro-environmental behavior (e.g. Bamberg \& Möser, 2007; Cottrell, 2003; Finger, 1994; Hansla et al., 2008; Hines et al., 1987; Hopper \& Nielsen, 1991). Environmental consequences of behaviors have also been found to influence household behaviors such as waste reduction, reuse of items, recycling actions, and green buying (Barr, 2007; Mainieri, Barnett, Valdero, Unipan, \& Oskamp, 1997; Roberts, 1996). However, the bulk of the literature pertaining to awareness of environmental consequences is focused on awareness campaigns and measuring their effectiveness (e.g. Campbell, de Heer, \& Kinslow, 2014; Hartley, Thompson, \& Pahl, 2015; Hopper \& Nielsen, 1991; Maibach, 1993; Marion \& Reid, 2007; Noe, Hull, \& Wellman, 1982; Reams, Geaghan, \& Gendron, 1996). Based on this research we formed the following hypothesis:

H3: The awareness of the environmental impacts of discarded cigarette butts will be significantly lower for smokers who improperly dispose of cigarette butts on a public beach than smokers who properly dispose of cigarette butts on a public beach.

Habit might be an overlooked predictor of cigarette but disposal. A habit is a tendency to repeat past behavior efficiently, and eventually automatically, as the behavior is performed frequently and extensively (Lally, Van Jaarsveld, Potts, \& Wardle, 2010; Neal, Wood, Labrecque, \& Lally, 2012). Researchers (Lally et al., 2010; Neal et al., 2012) have argued that contextual clues and frequency of the behavior drive habit formation. Neal et al. (2012) demonstrated the effect of contextual clues when they discovered that participants that frequently visited sports stadiums had a habit of speaking loudly in that setting. As a result, when those participants were given contextual clues (e.g. shown an image of a sports stadium) they responded by speaking loudly, such as they would typically do in that context. Lally et al. (2010) confirmed that behavior frequency is important to habit formation and that increasing the frequency of a behavior corresponds to an increase in the automaticity of the behavior, thus "supporting the assumption that repeating a behavior in a consistent setting increases automaticity" (i.e. creates habits) (p. 1006). Similarly, Neal et al. (2012) concluded that weak habits were "performed with lower frequency and/or in more variable contexts than strong habits" (p. 1).

Habits develop from repeating a behavior, and smokers may discard many cigarettes per day, thus repeating a discarding behavior (Neal, Wood, \& Quinn, 2006). Therefore, their chosen discarding behavior could develop into habitual, automatic behavior. Additionally, the mere presence of a cigarette butt to discard offers the contextual clue needed to form a habit. Therefore, the idea that a habit develops with a repetition of behavior and is activated by certain cues support the development of the following hypothesis:

H4: Smokers who improperly dispose of cigarette butts on a public beach will have a significantly higher habit of improperly discarding cigarette butts than smokers who properly dispose of cigarette butts on a public beach.

\section{Methods}

\subsection{Overview}

This mixed-mode study utilized both quantitative and qualitative research approaches. The combination of both research approaches "provides a more complete understanding of a research problem than either approach alone" (Creswell, 2009, p. 4). In the quantitative phase, the researchers examined the relationship between improper cigarette discarding behavior and the four predictor variables; habits, place attachment, environmental attitudes, and environmental awareness. 
Some issues related to cigarette butt disposal cannot be represented numerically "without distorting the essence of the social meanings they represent" (Hatch, 2002 p. 9). Therefore, it is appropriate to utilize a qualitative design when the researcher is trying to understand "how people interpret their experiences" (p. 5) around a specific phenomenon (Merriam \& Tisdell, 2016).

\subsection{Participant Selection}

Participants were purposefully selected utilizing criterion-based sampling; they all smoked on Jekyll Island's beaches and discarded their cigarette butts. Improper cigarette butt discarding consisted of failure to discard into a cigarette receptacle on the beach, a trash can, any other receptacle the participant provided and removed from the beach, or otherwise leaving behind a butt in a manner that could negatively impact the environment. Self-report bias was minimized by direct observation of participants' discarding behavior.

The number of willing participants the researcher could locate throughout the study period determined the sample size of the quantitative portion of the study. This resulted in 244 total participants.

The sample size of the qualitative portion of the study was determined by reaching the saturation point of information; the point at which the interviewer determined no new information was being obtained. This resulted in 28 participant interviews.

\subsection{Quantitative Study Design}

\subsubsection{Questionnaire}

The Self-Report Habit Index (SRHI) has been used to study "habit as a psychological construct, which has a number of facets, rather than simply defining habit as past behavioral frequency" (Verplanken \& Orbell, 2003, p. 21). The index measures habits based on a history of that behavior, as well as the automaticy ("lack of control, lack of awareness, efficiency") of said behavior (Verplanken \& Orbell, 2003, p. 3). Survey items were adapted to fit Jekyll Island's context and were measured with a 5-point Likert scale.

The place attachment scale was adopted from Williams (2000), and place names were adapted to refer specifically to Jekyll Island. The Environmental Attitudes Inventory (EAI) was used to measure environmental attitudes because it focuses on an individual's attitudes concerning the environment (Milfont \& Duckitt, 2010). The EAI is composed of 12 scales that measure "broad perceptions or beliefs regarding the natural environment" (p. 82), and responses have been found to be unaffected by social desirability. This study utilized portions of their "enjoyment of nature," "human dominance over nature," and "ecocentric concern" subscales and measured with a 5-point Likert scale.

Items measuring environmental awareness were created by the researchers to gauge individuals' awareness of the effect cigarette butts can have on the beach environment. Satisfactory face validity was determined upon review of the items by experts in survey item construction. Scoring ranged from 0-11. Participants were asked to correctly identify six materials present in a cigarette butt (e.g. cellulose acetate), and answer five true or false statements (e.g. metals in cigarette butts can leak out and pollute soil/sand).

\subsection{Qualitative Design}

The qualitative phase used a phenomenological case study approach. Phenomenological qualitative research focuses on describing the common experiences and meanings individuals give to a phenomenon (Creswell, 2013). Hatch (2002) states that the purpose of this type of study is to "reveal the essence of human experience" (p. 30). This research sought to understand factors that influence the behavior of improperly disposing of cigarette butts on Jekyll Island by examining participant's shared experiences with this phenomenon.

This study also utilized a case study methodological approach as this research sought to develop and portray an in-depth understanding of a phenomenon in a specific bounded system (Creswell, 2013). Case studies explore issues while utilizing the bounded system as a specific illustration (Creswell, 2013). The phenomenon of discarding a cigarette butt on the beach was studied within the bounded system of Jekyll Island's beaches. Therefore, the phenomenon was studied in-depth in one location and Jekyll Island serves as a specific illustration of the phenomenon.

A semi-structured qualitative interview protocol was designed and utilized in order to provide a more well-rounded view of the phenomenon of cigarette butt disposal behavior on Jekyll Island. The interviews allowed subjects to describe their point of view about the issue in question, thus allowing the researcher to "make sense of, or interpret, phenomena in terms of the meanings people bring to them" (Denzin \& Lincoln, 2005, p.3). This was important due to the complexities of behavioral influences that may be at play with cigarette butt disposal behavior. Asking open-ended questions with follow-up probing questions allowed the researcher to see the issue from the 
participant's standpoint rather than only interpreting the issue from the researcher's pre-designated questionnaire topics. The interview questions began with an ice breaker question, then progressed from least personal to most personal topics related to cigarette butt disposal behavior.

\subsection{Data Collection Process}

Prior to the commencement of this study, the researchers installed cigarette receptacles at six beach access points on Jekyll Island's oceanfront. The canisters were mounted onto poles that already contained trash and recycling receptacles.

\subsubsection{Survey Process}

One of the researchers collected data on Fridays, Saturdays, and Sundays from June $24^{\text {th }}$ until August $7^{\text {th }}, 2016$. Additionally, surveys were conducted on Monday, July $4^{\text {th }}$. The researcher was present on Jekyll Island's beaches for 6-9 hours per day based on the abundance of potential participants.

To locate smokers, the researcher walked transects in a north and south orientation on the beach between the two farthest access points. The researcher typically walked in a "channel" between the dunes and beachgoers to remain as inconspicuous as possible. It was easy to observe the smoking and discarding behavior inconspicuously from this location because the majority of beachgoers set up their beach gear at least a few yards closer to the water than to the dunes, and they always faced the water.

It was imperative that the researcher view the smoker during their subsequent cigarette butt discard. The researcher approached the smoker after determining if the cigarette butt disposal was "proper" or "improper." Then, the researcher asked if the potential participant would be willing to fill out a survey. The researcher asked random participants who had completed the survey if they would be willing to answer some follow-up open-ended questions.

\section{Results and Findings}

\subsection{Demographic Information}

The quantitative portion of this study was comprised of 244 participants, 107 (44\%) of these participants discarded their cigarette properly, while 137 (56\%) discarded their cigarette improperly. The age range of participants was 19-66 years with a mean age of 39 years. There were 109 males, 133 females, and 2 people who did not report their gender. Out of the 244 participants, 227 gave valid zip codes. This data showed that the distance participants lived from Jekyll Island ranged between 0-1947 miles, with an average distance of 231 miles away. Of the individuals that gave zip codes, 28 participants (12\%) were from the local area (Brunswick and Jekyll Island).

The qualitative portion of this study was comprised of a subset of the quantitative participants and included 28 individuals; $14(50 \%)$ of these participants discarded their cigarette properly, while $14(50 \%)$ discarded their cigarette improperly. The age range of participants was 23-63 years old with a mean age of 46 years. There were 16 males and 12 females. The range of distances participants lived from Jekyll Island was 24.5-1947 miles, with an average home distance of 311.84 miles away. Only one participant (4\%) was from the local area (Brunswick and/or Jekyll Island).

\subsection{Quantitative Results}

\subsubsection{Descriptive Statistics and Correlations}

Descriptive statistics and Pearson correlations provided the initial basis of analysis (Table 1). All four predictor variable scales had satisfactory internal reliability with Cronbach's alpha greater than .70 (Nunnally \& Bernstein, 1994). Cronbach's alpha is shown on the diagonal in Table 1.

Means and standard deviations for each variable are shown in Table 1. Environmental attitude, environmental awareness, and habit were significantly correlated with cigarette butt disposal, $r=-0.21, r=-0.22, r=0.27$ respectively (Table 1). There was no significant correlation $(r=0.00)$ between place attachment and cigarette butt disposal (Table 1).

Using logistic regression, habit, place attachment, environmental attitude, and environmental awareness as well as demographic factors (age and gender) were examined as potential predictors of improper cigarette disposal behavior. Four participants did not provide an age and were not included in the model. The logistic regression was performed in a stepwise fashion. Significance was set at $\mathrm{p}<.05$. The results can be found in Table 2 . 
Table 1. Descriptive Statistics and Correlation Matrix for Cigarette Butt Disposal and Predictor Variables (N=244)

\begin{tabular}{|c|c|c|c|c|c|c|c|c|}
\hline & Mean & S.D. & 1 & 2 & 3 & 4 & 5 & 6 \\
\hline 1. Cigarette Butt Disposal & 0.56 & 0.50 & & & & & & \\
\hline 2. Place Attachment & 3.19 & 1.03 & 0.00 & $(.95)$ & & & & \\
\hline 3. Environmental Attitude & 4.12 & 0.67 & $-0.21 * *$ & $0.33 * *$ & $(.72)$ & & & \\
\hline 4. Environmental Awareness & 6.13 & 1.78 & $-0.22 * *$ & -0.01 & $0.20 * *$ & $(.72)$ & & \\
\hline 5. Habit & 1.81 & 1.02 & $0.27 * *$ & -0.07 & $-0.20 * *$ & $-0.14 *$ & $(.94)$ & \\
\hline 6. Age & 38.94 & 11.52 & -0.05 & $0.19 * *$ & 0.03 & 0.00 & $-0.16^{*}$ & \\
\hline 7. Gender & 0.55 & 0.50 & -0.12 & $0.13^{*}$ & $0.15^{*}$ & 0.03 & -0.09 & 0.04 \\
\hline
\end{tabular}

Note. Reliability coefficient estimates $(\alpha)$ are in Parenthesis along diagonals. $* \mathrm{p}<0.05 ; * \mathrm{*} p<0.01$. (Two-tailed tests).

Table 2. Summary of the Logistic Regression

\begin{tabular}{llllllll}
\hline Variable & B & S.E. & Wald & df & Sig. & Exp(B) & Nagelkerke $R^{2}$ Change \\
\hline Age & -0.004 & 0.013 & 0.095 & 1 & 0.757 & 0.996 & \\
Gender & -0.365 & 0.286 & 1.631 & 1 & 0.202 & 0.694 & \\
Place Attachment & 0.160 & 0.150 & 1.137 & 1 & 0.286 & 1.174 & 0.022 \\
Environmental Attitude & -0.534 & 0.242 & 4.854 & 1 & 0.028 & 0.586 & 0.062 \\
Environmental Awareness & -0.191 & 0.082 & 5.442 & 1 & 0.020 & 0.826 & 0.037 \\
Habit & 0.501 & 0.160 & 9.784 & 1 & 0.002 & 1.650 & 0.055 \\
Constant & 2.603 & 1.249 & 4.343 & 1 & 0.037 & 13.507 & \\
\hline
\end{tabular}

The overall model was significant, $\chi^{2}(6, \mathrm{~N}=239)=33.64, p=0.00$ which indicates that the model is a good fit, and it predicts significant variability in the data. Specifically, the Nagelkerke $R^{2}$ value $(0.176)$ shows that all of the variables in combination with the demographic information predict $17.6 \%$ of the variability in the data.

Block (step) one, which included only demographics (age and gender), was not significant $\chi^{2}(2, \mathrm{~N}=239)=3.89$, $p=0.143$. The Nagelkerke $R^{2}$ value (.022) shows that only $2.2 \%$ of the variability in the data could be due to the demographic factors.

Block (step) two added place attachment. This step was not significant $\chi^{2}(3, \mathrm{~N}=239)=3.98, p=0.264$. The Nagelkerke $R^{2}$ value for the block was 0.022 . Place attachment did not add any explanation of the variability in the data. Thus, hypothesis 1 was not accepted.

Block (step) three added environmental attitudes. This step was significant $\chi^{2}(4, \mathrm{~N}=239)=15.433, p=0.004$. The Nagelkerke $R^{2}$ value for the block (0.084) shows that $8.4 \%$ of the variability in the data could be due to the combination of demographic factors, place attachment, and environmental attitudes. The Nagelkerke $R^{2}$ change (0.062) indicates that environmental attitudes explained $6.2 \%$ of the variability in the model. Thus, hypothesis 2 was accepted.

Block (step) four added environmental awareness. This step was significant $\chi^{2}(5, \mathrm{~N}=239)=22.644, p=0.000$. The Nagelkerke $R^{2}$ value for the block (0.121) shows that $12.1 \%$ of the variability in the data could be due to the combination of demographic factors, place attachment, environmental attitudes, and environmental awareness. The Nagelkerke $R^{2}$ change (0.037) indicates that environmental awareness explained $3.7 \%$ of the variability in the model. Thus, hypothesis 3 was accepted.

Block (step) five added the final variable of habit. This step represents the overall model, and it was significant, $\chi^{2}$ $(6, \mathrm{~N}=239)=33.64, p=0.00$. The Nagelkerke $R^{2}$ change $(0.055)$ indicates that habit explained $5.5 \%$ of the variability in the overall model. Thus, hypothesis 4 was accepted.

\subsection{Qualitative Findings - Proper Discarders}

The qualitative data analysis followed the procedure outlined by Creswell (2013). The researcher transcribed the recorded interviews into Microsoft Word documents. Next, the researcher read the transcripts several times to get a sense of the interview as a whole (Creswell, 2013). MAXQDA computer software was used to code and analyze the data (VERBI Software GmbH, Version 12, 2015). A list of significant statements was developed about how 
participants experienced the phenomenon of discarding a cigarette butt while on the beach. These statements were then grouped into units based on their meaning, thus creating codes. These codes were then assorted into general themes pertaining to common ideas. These themes were described using textural descriptions to illustrate what the participants experienced. Verbatim statements were used to support the researcher's findings and illustrate the meanings participants gave the themes.

It would be preferable to validate these qualitative findings by utilizing member checking where one presents their findings to the originally-surveyed population and solicits feedback on the accuracy of their findings. However, participants were not asked for follow up contact information to protect their privacy, so this was not possible. Validation was conducted by two reviews of the coding process by experts in qualitative research methods. Peer reviewers were also utilized to play "devil's advocate" about the findings, thus shedding light on potential areas of misinterpretation. The themes described in this section are derived from the participants who discarded their cigarette butt properly.

\subsubsection{Theme 1: Litter}

Many proper-discarding participants considered cigarette butts to be litter. For example, a number of participants explicitly stated that a cigarette butt is "trash." Participants also indicated that general litter was bad, and that "any trash [laying around] is not good."

3.3.1.1 Appearance. Several participants expanded to say that a reason these "butts" should not be on the ground is that they are "unsightly." The concern was that the cigarette butts are an "eyesore, a dirty, filthy eyesore." Participants did not want trash visible on the beach. Cigarette butts lying on the ground was also a problem because participants stated that they swell up and break open and are then a larger pile of trash that takes away from the aesthetics of the beach.

3.3.1.2 Time. Participants explained that cigarette butts take a long time to break down, noting that cigarettes "take forever" to disintegrate. Because of the amount of time to break down, some participants expressed concern that the butts could have further impacts than just their ugly appearance. For example, a participant stated, "it could take 50 years for it to break down and at that point in time it's probably been incorporated into somebody's nest."

\subsubsection{Theme 2: Social Awareness}

The proper-discarding participants indicated that they were socially aware, or aware of social constructs within the culture around them. This was demonstrated by their feelings of belonging to a stigmatized group and being aware that their smoking actions impacted others.

3.3.2.1 Stigmatized Group Identity. It was clear these participants identify as a group that performs a behavior that is judged by others and is stigmatized by negative perceptions. For example, participants commented on how they felt like they belonged to a "minority group" of people who smoke in society, and it was noted that fewer people are smoking, therefore furthering the feelings of being in a minority group. A number of participants also spoke about how "people don't like people smoking anymore," so it was clear that they perceived their smoking behavior to be socially unacceptable. One person told how it was "hurtful to walk around and see so many [cigarette butts]." This "hurt" comes from feeling that his group is performing socially unacceptable behavior of smoking and the improperly discarded cigarette butts simply give non-smokers a reason to believe that smokers are bad people.

3.3.2.2 Behavior May Affect Others. Because participants were socially aware, they recognized that their smoking and cigarette discarding behavior may negatively affect others' beach experiences. For example, a participant described how Jekyll Island was "a family beach and not everybody wants to be exposed to cigarette smoke." Additionally, smoking was seen as a personal choice that should not affect others. One woman stated, "I know [smoking] is bad for me, whatever. I still choose to do it, that's my choice, but I'm also very conscientious that it is my choice, not anybody else's choice."

\subsubsection{Theme 3: Cumulative Effects Mean Negative Consequences}

Participants were concerned that "if everybody's doing it [discarding their cigarette butts onto the ground]" there would be negative consequences. These consequences included an accumulation of toxins in the ecosystem and a potential ban on smoking.

3.3.3.1 Environmental Toxins. Participants were concerned that an accumulation of cigarette butts would be "a bad thing." Specifically, they indicated this would cause "poisons" to end up in the surrounding ecosystems. One person acknowledged that when a person smokes, they draw a number of chemicals, including nicotine and carcinogens, into the filter. Then, when the butt is discarded onto the ground that filter holds chemicals that can affect everything in the environment. 
3.3.3.2 Potential Smoking Ban. Participants recognized that the cumulative effects of many smokers discarding their "butts" improperly would result in a large number of cigarette butts on the beach, which could in turn result in a ban on smoking to prevent this issue. Importantly, having a smoking ban on the beach was a concern for them because they appreciated that they could smoke on Jekyll's beaches. Participants noted that "it's [smoking] still allowed here, it's part of why I come here." One participant tried to prevent a smoking ban saying that she helped pick up after other people because "if there are cigarette butts left all over" then her right to smoke on the beach could be taken away.

\subsubsection{Theme 4: Minimal Obstacles.}

Participants perceived minimal obstacles to discarding their cigarettes properly. This was because they believed proper discarding took little effort, a small amount of time, and required no planning.

3.3.4.1 Little Time and Effort. Participants said discarding their cigarette butts properly required little to no effort. They stated that finding a place to put a cigarette butt did not require a lot of thought, calling it something that they "didn't even think twice about." They even stated that bringing a cigarette to the beach required more effort than taking it back. Participants also mentioned how discarding their cigarette butt properly required only a little bit of time. One stated that the time it took was "not a big deal."

3.3.4.2 Doesn't Require Planning. It was very clear that participants did not feel that they had to plan ahead to discard their cigarette butts properly. In other words, they did not feel that they needed to plan to bring an item with them specifically for this task. Instead, there was an attitude that the items they already had could be utilized. One participant said, "you can always make something or find something that you're going to throw away anyway." The item utilized depended on what they had with them, but there was agreement that they would use "whatever you can find." Participants also talked about using regular trash cans, as long as they extinguished the cigarette first to prevent fire.

\subsubsection{Theme 5: Personally Responsible}

Participants believed that it was their responsibility to take their cigarette butts with them and then dispose of the butts properly. Additionally, they extended this belief to everyone, including non-smokers, saying that it was each person's responsibility to pick up their trash. One participant stated this idea nicely; "if you are making trash then you take it with you and you dispose of it properly." A number of proper discarders also recognized that if they didn't properly discard their cigarette butts, no one else was going to pick them up for them. As an example, one person stated "it's irresponsible to throw your trash in any type of natural setting and expect that-- who's going to clean it up?"

\subsection{Qualitative Findings - Improper Discarders}

The themes described in this section are derived from the participants who improperly discarded their cigarette butt.

\subsubsection{Theme 1: Litter or Not?}

From these interviews, it appeared that there is some confusion among improper-discarding participants about cigarette butts being litter or not. Some participants expressed that discarding a cigarette butt onto the ground is considered litter by directly stating throwing butts on the ground "[is] pretty much littering." In contrast to this, some participants noted that they were unconcerned about cigarette butts being discarded onto the ground because "I figure it's harmless." Additionally, one man justified his discarding behavior by stating that cigarette butts are not bad in comparison to other issues, "You've got to look at the amount of cigarette butts and the impact on the environment from the cigarette butts. I think it's minimal compared to the other stuff we've got going on."

\subsubsection{Theme 2: Lack of Knowledge}

This theme clearly exposed two areas where participants lacked knowledge. Participants didn't understand what components were in a cigarette butt and they did not know about the environmental impacts that a cigarette butt can have when discarded onto the ground.

3.4.2.1 Lack of Knowledge about Components of a Cigarette Butt. When participants were asked about the materials that cigarette butts contained, it was clear that they did not have an understanding of this topic. Participants stated that there were chemicals, metals, and plastics, in them, but the answers were very vague, quite often including non-descriptive statements such as "whatever materials." Often participants said they weren't sure. One participant stated this lack of knowledge outright; "I'm not exactly sure what's in a cigarette butt." Another participant echoed this sentiment and noted, "I'm pretty sure they might leak something out of the filters, nicotine or whatever." 
3.4.2.2 Lack of Knowledge of Environmental Impacts. It can be expected that if one does not know what materials are in the product they are discarding onto the ground, they would not be able to express how that item may affect the environment. This sub-theme brought to light the inability of some of the participants to express how their cigarette butt being discarded onto the ground would impact the environment. Again, answers were very vague such as "I just know that there's a lot of cons," and participants sometimes searched for confirmation from the researcher that their answer was correct. For example, one woman stated, "I don't know. I'm sure it does something bad to this [the beach environment]. Right?"

\subsubsection{Theme 3: Problems with Cigarette Receptacles.}

Cigarette receptacles were available to all participants as they entered or exited the beach. However, during interviews, it was discovered that there were problems with those cigarette receptacles. These problems are described in the sub-themes below.

3.4.3.1 Cigarette Receptacles not Convenient. Participants noted that they wanted the cigarette receptacles to be more convenient for them by placing receptacles both on the beach, and at the beach access points. Participants recognized that placing the receptacles on the beach would not be wise due to the tidal change, but it was suggested that receptacles be "spread out along the edge of the dunes," every couple hundred feet or so. Participants stated that a useful place to put cigarette receptacles would be "anywhere that's going to have a lot of people coming through it," such as "on the end of the guardrail, or where you've got the trash cans up they could have one on each side."

3.4.3.2 Not Recognizing Receptacles. The irony of what participants were describing about cigarette receptacle placement is that the cigarette receptacles available at the beach were located where many of the participants were stating they should be; they were mounted on trash can poles where people entered or exited the beach. In fact, after being shown the receptacle on the trash can pole nearest her, one participant noted that "that's really good placement...it's everything I said."

The participants expressed being accustomed to looking for particular smoking accommodations, and they stated that the small black receptacles were "not something that we're recognizing. We recognize the tall standing thing." Participants also expressed frustration that there were no designated smoking areas that they typically look for; "it would be nice if they had a little smoking area set up with ashtrays where they could be disposed of ... designated areas."

3.4.3.3 Didn't See the Receptacles. An additional explanation for the discrepancy between suggested receptacle placement and being observed improperly discarding a cigarette butt may lie in simply not seeing the receptacle canisters. More than half of improper discarders noted that they had not seen the receptacles, "Oh I hadn't seen it, but I see it now!" Sometimes, even after drawing their attention to the receptacle, participants still had trouble seeing them, "Yeah, barely see it. It seems to me like it's blending into the pole." Additionally, upon being asked if they had looked for receptacles participants often stated that they had in fact looked for a proper receptacle but had seen only the trash cans, not the cigarette receptacles; "I did [look for a cigarette receptacle] and I didn't see anything. I was thinking that was just trash there." Participants also appeared to look for signage to help them identify various smoker accommodations.

\subsubsection{Theme 4: Conscious Choice Required}

The fourth theme involved participants recognizing that a conscious choice had to be made if they were to dispose of butts in a way contrary to how they had done it in the past. However, that is not to say that the "automatic" reaction was to discard it on the ground. This theme emerged when participants were asked what kind of effort it would take for them to use an alternative method of discarding. Participants noted that they have to make a decision about where to discard their "butts," and this requires "a conscious effort." Participants didn't believe that this was necessarily a difficult thought process or one that required a lot of effort, but they did acknowledge that it required a conscious choice about how they wanted to discard the butt. For example, some participants spoke about how discarding properly would require them to "find a place to put it [the cigarette butt]," and to find that place they would have to think about where to put the butt.

\subsubsection{Theme 5: Statements Contradict Behavior Observed}

This theme represents statements given by individuals that contradict the improper discarding behavior that they were observed doing. It encompasses statements that appear to have a social awareness quality to them. In other words, participants expressed statements that were most likely to appear to be "socially acceptable." Social desirability bias, the tendency for individuals to "deny socially undesirable traits and to claim socially desirable ones," may have been at play (Nederhof, p. 264, 1985). 
3.4.5.1 Reported do not Leave Cigarette Butts on Ground. The most common "contradictory" statement made (stated by 12 out of 14 participants) was the participant describing that they do not leave their cigarette butts on the ground. Instead, individuals often cited other locations where they claimed to put their cigarette butt such as into their pocket, into a used soda can, or into a trash can. The common thread amongst these statements was an adamant claim that they did not discard their cigarette butts onto the ground, but unbeknownst to them, they had just been observed improperly discarding the butt. For example, the researcher observed two participants smoking while walking down the beach along the water's edge. Both participants discarded the butts into the ocean. When interviewing these participants shortly after their discarding, they both stated that they never discard improperly and that they discard their butts into a used beverage can.

3.4.5.2 Awareness of Fire. Starting a fire from a discarded cigarette butt was another "contradictory" concern expressed by participants. If an individual is discarding their cigarette butt onto the ground, they would not be expected to report being concerned about fire since their actions are contributing to the chance of that fire. However, statements made by participants often indicated that they did in fact consider the risk of starting a fire. For example, one woman said that when discarding her cigarette butt she thinks about the fact that "I need to put that out and make sure it's totally out so that we don't catch anything on fire by being careless." Similar to results in other studies (e.g. Bagley et al. 2012), some improper discarders noted the fire danger posed by cigarette butts discarded in trash cans, yet did not properly discard in proper receptacles available at the beach.

3.4.5.3 Laws and Fines. Laws, and subsequent fines associated with them, was something that several participants showed concern about. Specifically, participants expressed concern that at some point non-smoking laws could be instituted on the beach. Again, this theme is contradictory to their observed improper cigarette disposal because the participants recognized that their actions of discarding their cigarette butt onto the ground could lead to the institution of anti-smoking laws on the beach, yet they still discarded improperly. A participant stated that if people continue to discard cigarettes onto the ground "the government's going to say "no smoking on the beach" showing clear concern that his smoking freedoms on the beach could be restricted.

3.4.5.4 Feelings of Personal Responsibility. The majority of participants talked about feeling personally responsible for their cigarette waste. This theme contradicts participants' observed improper discarding actions because despite expressing feelings of personal responsibility, participants were still observed discarding onto the ground. Sometimes, this personal responsibility was cited as being an inherent responsibility of being a smoker, for example, "it's your right to smoke and your freedom to smoke. Keep it clean. It's just common sense to me."

3.4.5.5 Impact on Other People. Additionally, participants also expressed feeling personally responsible for preventing their cigarette waste from impacting other people. Participants indicated that discarded cigarette butts lying on the beach can cause "eyesores" for other beachgoers. A woman expressed a desire not to ruin the beach experience for anyone when she said, "I don't want to ruin any kind of experience for anyone else. I don't want someone to come up and be like 'oh, there was trash on the ground' you know and it be because of me." However, these statements contradict their observed improper disposal because if an individual disposed of their cigarette butt improperly, they would be contributing to those "eyesores" on the beach. Participants also acknowledged that people could step on a cigarette butt, yet still improperly discarded.

3.4.5.6 Thinking about Nature. Participants often mentioned that they were thinking about various aspects of nature, often implying that they do not improperly discard their cigarette butts because they value nature. However, these statements contradict their observed actions of discarding improperly because their cigarette butts are entering the natural environment they indicated they cared about. For example, one participant stated, "I fish. I spend a lot of time in the ocean and I understand what it's like to see a sea turtle out at sea, even raised with plastic stuck to them." Another participant said that she thinks about nature when choosing how to discard her cigarette butt specifically when she is on Jekyll because she is more aware of the impact that butt could have. She stated, "I see the birds right there and it's in my face and I think 'I don't want them to get them.' [And.... I don't want the fish to eat them. I just don't want to hurt them."

3.4.5.7 Knowledge that a Cigarette Butt can Impact the Environment. In a number of instances, participants described ways that the environment could be impacted by improper cigarette butt disposal, specifically that animals could be impacted and that cigarette butts are not biodegradable. Again, if a smoker has an understanding of how their discarded cigarette butt could negatively impact the environment; it's surprising that they would discard improperly. Their statements contradicted their actions - insinuating the old admonition "do as I say not as I do".

3.4.5.8 Social Norm is Clean Beaches. A few participants specifically noted the cleanliness of Jekyll's beaches stating, "It's clean." Some participants elaborated on this to refer directly to cigarette butts stating, "It's very clean. 
I don't see cigarette butts laying around anywhere." These statements are important because they indicate that participants observed that others keep the beach clean. Their statements indicate they have perceived keeping the beach clean is what's normal or typical in that setting (i.e. the descriptive norm is a clean beach). Therefore, they acknowledge external pressure to also keep the beach clean.

A number of improper discarders indicated they understood that others disapproved of their discarding cigarette butts onto the beach. Their statements indicated they sensed there was an expectation to not discard cigarette butts on the beach. Statements about beach cleanliness and disapproval of improper discarding illustrate that improper discarders understood the social norm of Jekyll Island was to have a clean beach, yet their actions of throwing their cigarette butt on the beach contradict their understanding of the social norm.

3.4.5.9 Discarding Behavior at Jekyll Island Similar to Other Places. When participants were asked if their experience as a smoker was different at Jekyll Island than another public area the majority of participants indicated that their behavior was no different, stating that their behavior doesn't change based on their location. For example, "it's not [any different]. I treat it the same wherever I go."

Interestingly, a large number of the individuals that stated location, or Jekyll Island, didn't impact their experience of being a smoker also described that they always discard their butts properly, but this contradicts their observed behavior. For example, one participant said, "it's [discarding properly into a used beverage container] natural and what we do whether we're at home, out shopping, whether we're at a public forum like this" yet, moments before, they had been observed discarding their cigarette butt onto the ground.

\section{Discussion}

Quantitative results indicate that environmental attitudes, environmental awareness, and habits were significant factors in improper cigarette butt disposal behavior. Smokers with a lower pro-environmental attitude were more likely to discard their cigarette butt improperly. This result aligns with previous research by Hines et al. (1987) who found a positive relationship between environmental attitudes and pro-environmental behavior; individuals with stronger pro-environmental attitudes were more likely to engage in pro-environmental behavior than individuals with weaker pro-environmental attitudes.

Smokers who were less aware of the environmental consequences of improper cigarette butt discarding were more likely to discard improperly. This result is supported by previous research that found that individuals who recognize there are adverse environmental problems as a consequence of their behavior may be influenced by that knowledge to protect the environment or develop a personal or moral norm that subsequently guides their behavior to be more pro-environmental, as illustrated in the norm-activation theory of altruistic behavior (Hansla et al., 2008; Schwartz, 1977).

Habit was also found to strongly affect discarding behavior. This confirms that as improper cigarette discarding on a beach becomes more habitual, the person is more likely to improperly discard cigarette butts. Place attachment, however, was not a significant predictor of improper discarding.

Themes derived from interviews with individuals who improperly discarded cigarette butts revealed some confusion about whether butts are litter, a lack of knowledge of environmental impacts, problems with the cigarette receptacles currently in place, the requirement of a conscious choice about how to discard a butt, and statements that contradicted the behavior observed. Interviews with individuals who properly disposed of their cigarette butts illustrated themes recognizing cigarette butts as litter, social awareness, understanding the cumulative environmental effects of cigarette butts on the beach, perceived minimal obstacles to discarding properly, and feelings of personal responsibility.

Addressing problems caused by human behavior, such as improperly discarding cigarette butts on public beaches, requires a multi-faceted approach. Our findings suggest that the most effective behavioral interventions (to reduce improper cigarette butt discarding) should address each of the following aspects: promoting pro-environmental attitudes, altering habitual improper discarding, promoting awareness of how cigarette butts impact the environment, and minimizing barriers to proper discarding. Given the importance of place attachment on behavior in recreational settings and natural landscapes in previous studies (e.g. Ramkissoon et al., 2012; Williams \& Vaske, 2003), and that only a small number of participants were from the local area, campaigns to increase place attachment may also be prudent despite our results. Utilizing a holistic intervention strategy will likely be the most effective at reducing cigarette litter on beaches.

Pro-environmental attitudes should be fostered. Environmental attitude change can potentially be encouraged through cognitive dissonance (Jhangiani, Tarry, \& Stangor, 2015), such as pointing out to an improper discarder that their discarding behavior is socially unacceptable. Raising awareness of cigarette butts as litter with serious 
environmental consequences and the need for personal responsibility, such as through informational campaigns, may influence improper discarders to alter their behavior. However, simply bringing awareness about an environmental problem rarely results in behavior changes, unless the behavior is considered convenient (Steg \& Vlek, 2009). Therefore, informational campaigns must be paired with interventions to make proper discarding more convenient.

Adding cigarette disposal receptacles could be effective at reducing cigarette butt litter on public beaches when implemented in conjunction with additional intervention approaches. The increased presence of receptacles could create a context shift needed to alter habitual discarding behavior (Verplanken \& Wood, 2006). Placing receptacles at all beach access points could create an expectation of use. Receptacles need to be well marked, convenient and accessible, recognizable, and specifically for cigarettes. Given the cumulative environmental impact of cigarette butts in beach environments it seems that banning smoking on public beaches or creating designated smoking areas would be advisable. However, in areas where the economy relies heavily on the tourism industry, such as Jekyll Island, it may not be wise to ban activities that discourage some visitors.

\section{Acknowledgments}

The University of Nebraska-Lincoln, School of Natural Resources provided financial support of this research.

\section{References}

Addamo, A. M., Laroche, P., Hanke, G. (2017). Top Marine Beach Litter Items in Europe. Luxembourg: Office of the European Union.

Ajzen, I. (1991). The theory of planned behavior. Organizational Behavior and Human Decision Processes, 50, 179-211. https://doi.org/10.1016/0749-5978(91)90020-T

Bagley, A., Salazar, D., Wetmore, D., \& Wolff, A. (2012). Cigarette butts in Santa Barbara. Unpublished manuscript, University of California - Santa Barbara. Retrieved from https:/www.santabarbaraca.gov/civicax/filebank/blobdload.aspx?BlobID=45662

Balderjahn, I. (1988). Personality variables and environmental attitudes as predictors of ecologically responsible consumption patterns. Journal of Business Research, 17, 51-56. https://doi.org/10.1016/01482963(88)90022-7

Bamberg, S., \& Möser, G. (2007). Twenty years after Hines, Hungerford, and Tomera: A new meta-analysis of psycho-social determinants of pro-environmental behaviour. Journal of Environmental Psychology, 27, 1425. https://doi.org/10.1016/j.jenvp.2006.12.002

Barr, S. (2007). Factors influencing environmental attitudes and behaviors: A UK case study of household waste management. Environment and Behavior, 39, 435-473. https://doi.org/10.1177/0013916505283421

Campbell, M. L., de Heer, C. P., \& Kinslow, A. (2014). Littering dynamics in a coastal industrial setting: The influence of non-resident populations. Marine Pollution Bulletin, 80, 179-185. https://doi.org/10.1016/j.marpolbul.2014.01.015

Cialdini, R. B., Reno, R. R., \& Kallgren, C. A. (1990). A focus theory of normative conduct: Recycling the concept of norms to reduce littering in public places. Journal of Personality and Social Psychology, 58, 1015. https://doi.org/10.1016/S0065-2601(08)60330-5

Cottrell, S. P. (2003). Influence of sociodemographics and environmental attitudes on general responsible environmental behavior among recreational boaters. Environment and Behavior, 35, 347-375. https://doi.org/10.1177/0013916503035003003

Creswell J. W. (2009). Research design: Qualitative, quantitative, and mixed methods approaches ( $3^{\text {rd }}$ ed.). Thousand Oaks, CA: Sage Publications.

Creswell, J. W. (2013). Qualitative inquiry and research design: Choosing among five approaches ( $3^{\text {rd }}$ edition). Thousand Oaks, CA: Sage.

Denzin, N. K., \& Lincoln, Y. S. (2005). Introductions: The discipline and practice of qualitative research. In N. K. Denzin \& Y. S. Lincoln (Eds.), The sage handbook of qualitative research (pp. 1-32). Thousand Oaks, CA: Sage.

Diekmann, A., \& Preisendörfer, P. (2003). Green and greenback the behavioral effects of environmental attitudes in low-cost and high-cost situations. Rationality and Society, 15, 441-472. https://doi.org/10.1177/1043463103154002 
Dodds, R., \& Holmes, R. M. (2019). Beach tourists: What factors satisfy them and drive them to return. Ocean and Coastal Management, 168, 158-166. https://doi.org/10.1016/j.ocecoaman.2018.10.034

Eagly, A. H., \& Chaiken, S. (1993). The psychology of attitudes. Fort Worth, TX: Harcourt Brace Jovanovich College Publishers.

Finger, M. (1994). From knowledge to action? Exploring the relationships between environmental experiences, learning, and behavior. Journal of Social Issues, 50, 141-160. https://doi.org/10.1111/j.15404560.1994.tb02424.x

Floress, K., Akamani, K., Halvorsen, K. E., Kozich, A., T., \& Davenport, M. (2015). The role of social science in successfully implementing watershed management strategies. Journal of Contemporary Water Research and Education, 154, 85-105. https://doi.org/10.1111/j.1936-704X.2015.03189.x

Giuliani, M. V. (2003). Theory of attachment and place attachment. In M. Bonnes, T. Lee, \& M. Bonaiuto (Eds.), Psychological theories for environmental issues (pp. 137-170). New York: Rutledge.

Green, J. (2018). Marine Debris initiative. The Magazine of Jekyll Island, 3(1), 21-23.

Grunert, S. C., \& Juhl, H. J. (1995). Values, environmental attitudes, and buying of organic foods. Journal of Economic Psychology, 16, 39-62. https://doi.org/10.1016/0167-4870(94)00034-8

Hansla, A., Gamble, A., Juliusson, A., \& Gärling, T. (2008). The relationships between awareness of consequences, environmental concern, and value orientations. Journal of Environmental Psychology, 28, 1-9. https://doi.org/10.1016/j.jenvp.2007.08.004

Hartley, B. L., Thompson, R. C., \& Pahl, S. (2015). Marine litter education boosts children's understanding and $\begin{array}{lllll}\text { self-reported } \quad \text { Marine } & \text { Pollution } & \text { Bulletin, } & 909-217 .\end{array}$ https://doi.org/10.1016/j.marpolbul.2014.10.049

Hatch, J. A. (2002). Doing qualitative research in educational settings. Albany: State University of New York Press. Ch. 1: Deciding to do a qualitative study.

Hernández, B., Martín, A. M., Ruiz, C., \& Hidalgo, M. C. (2010). The role of place identity and place attachment in breaking environmental protection laws. Journal of Environmental Psychology, 30(3), 281-288.

Hines, J. M., Hungerford, H. R., \& Tomera, A. N. (1987). Analysis and synthesis of research on responsible environmental behavior: A meta-analysis. The Journal of Environmental Education, 18, 1-8. https://doi.org/10.1080/00958964.1987.9943482

Hopper, J. R., \& Nielsen, J. M. (1991). Recycling as altruistic behavior normative and behavioral strategies to expand participation in a community recycling program. Environment and Behavior, 23, $195-220$. https://doi.org/10.1177/0013916591232004

Jekyll Island Authority. (2014). Jekyll Island master plan 2014. Retrieved from http://www.jekyllisland.com/wpcontent/uploads/2014/02/JekyllIslandMasterPlanFinal.pdf

Jekyll Island Authority. (2015). Jekyll Island authority progress report 2015. Retrieved from https://issuu.com/jekyllisland/docs/2015_progress_report_hires

Jhangiani, R., Tarry, H., \& Stangor, C. (2015). Changing attitudes by changing behavior. In R. Jhangiani, \& H. Tarry (Eds.), Principles of social psychology - 1st International edition (182-195). Vancouver, Canada: BC Campus.

Jorgensen, B. S., \& Stedman, R. C. (2001). Sense of place as an attitude: Lakeshore owners attitudes toward their properties. Journal of Environmental Psychology, 21, 233-248. https://doi.org/10.1006/jevp.2001.0226

Kollmuss, A., \& Ageyman, J. (2002). Why do people act environmentally and what are the barriers to proenvironmental behavior? Environmental Education Research, 8, 239-260. https://doi.org/10.1080/13504620220145401

Kyle, G. T., Absher, J. D., \& Graefe, A. R. (2003). The moderating role of place attachment on the relationship between attitudes toward fees and spending preferences. Leisure Sciences, 25, 33-50. https://doi.org/10.1080/01490400306552

Kyle, G., Graefe, A., Manning, R., \& Bacon, J. (2004). Effects of place attachment on users' perceptions of social and environmental conditions in a natural setting. Journal of Environmental Psychology, 24, $213-225$. https://doi.org/10.1016/j.jenvp.2003.12.006 
Lally, P., Van Jaarsveld, C. H., Potts, H. W., \& Wardle, J. (2010). How are habits formed: Modelling habit formation in the real world. European Journal of Social Psychology, 40, 998-1009. https://doi.org/10.1002/ejsp.674

Lin, P. C., \& Huang, Y. H. (2012). The influence factors on choice behavior regarding green products based on the theory of consumption values. Journal of Cleaner Production, 22, 11-18. https://doi.org/10.1016/j.jclepro.2011.10.002

Maibach, E. (1993). Social marketing for the environment: Using information campaigns to promote environmental awareness and behavior change. Health Promotion International, 8, 209-224. https://doi.org/10.1093/heapro/8.3.209

Mainieri, T., Barnett, E. G., Valdero, T. R., Unipan, J. B., \& Oskamp, S. (1997). Green buying: The influence of environmental concern on consumer behavior. The Journal of Social Psychology, 137, 189-204. https://doi.org/10.1080/00224549709595430

Marion, J. L., \& Reid, S. E. (2007). Minimising visitor impacts to protected areas: The efficacy of low impact education programmes. Journal of Sustainable Tourism, 15, 5-27. https://doi.org/10.2167/jost593.0

Merriam, S., \& Tisdell, E.J. (2016). Qualitative research: A guide to design and implementation (4 ${ }^{\text {th }}$ edition). San Francisco: John Wiley and Sons.

Micevska, T., Warne, M. St. J., Pablo, F., \& Patra, R. (2006). Variation in, and causes of, toxicity of cigarette butts to a cladoceran and microtox. Archives of Environmental Contamination and Toxicology, 50, 205-212. https://doi.org/10.1007/s00244-004-0132-y

Milfont, T. L., \& Duckitt, J. (2010). The environmental attitudes inventory: A valid and reliable measure to assess the structure of environmental attitudes. Journal of Environmental Psychology, 30, 80-94. https://doi.org/10.1016/j.jenvp.2009.09.001

Moerman, J. W., \& Potts, G. E. (2011). Analysis of metals leached from smoked cigarette litter. Tobacco Control, 20, 30-5. http://dx.doi.org/10.1136/tc.2010.040196

Moriwaki, H., Kitajima, S., Katahira, K. (2009). Waste on the roadside, 'poi-sute' waste: Its distribution and elution potential of pollutants into environment. Waste Management, 29, 1192-1197. https://doi.org/10.1016/j.wasman.2008.08.017

Neal, D. T., Wood, W., Labrecque, J. S., \& Lally, P. (2012). How do habits guide behavior? Perceived and actual triggers of habits in daily life. Journal of Experimental Social Psychology, 48, 492-498. https://doi.org/10.1016/j.jesp.2011.10.011

Neal, D. T., Wood, W., \& Quinn, J. M. (2006). Habits-A repeat performance. Current Directions in Psychological Science, 15, 198-202. https://doi.org/10.1111/j.1467-8721.2006.00435.x

Nederhof, A. J. (1985). Methods of coping with social desirability bias: A review. European Journal of Social Psychology, 15, 263-280. https://doi.org/10.1002/ejsp.2420150303

Newhouse, N. (1990). Implications of attitude and behavior research for environmental conservation. The Journal of Environmental Education, 22, 26-32. https://doi.org/10.1080/00958964.1990.9943043

Noe, F., Hull, R., \& Wellman, J. (1982). Normative response and norm activation among ORV users within a seashore environment. Leisure Sciences, 5, 127-142. https://doi.org/10.1080/01490408209512997

Novotny, T. E., Hardin, S. N., Hovda, L. R., Novotny, D. J., McLean, M. K., \& Khan, S. (2011). Tobacco and cigarette butt consumption in humans and animals. Tobacco Control, 20, 17-20. http://dx.doi.org/10.1136/tc.2011.043489

Novotny, T. E., Lum, K., Smith, E., Wang, V., \& Barnes, R. (2009). Cigarettes butts and the case for an environmental policy on hazardous cigarette waste. International Journal of Environmental Research and Public Health, 6, 1691-1705. http://dx.doi.org/10.1136/tobaccocontrol-2015-052737

Nunnally, J. C., \& Bernstein, I. H. (1994). Psychometric theory. New York: McGraw-Hill.

Nugent, P. (2013). Consequence. Retrieved from https://psychologydictionary.org/consequence/

Ocean Conservancy. (2019). The beach and beyond: International coastal cleanup 2019 report. Retrieved from https://oceanconservancy.org/wp-content/uploads/2019/09/Final-2019-ICC-Report.pdf 
Ouellette, J. A., \& Wood, W. (1998). Habit and intention in everyday life: The multiple processes by which past behavior predicts future behavior. Psychological Bulletin, 124, 54. https://doi.org/10.1037/00332909.124.1.54

Pam, N. (2013). What is environmental attitudes. Psychology Dictionary. Retrieved from http://psychologydictionary.org/environmental-attitudes/

Puls, J., Wilson, S. A., \& Hölter, D. (2011). Degradation of cellulose acetate-based materials: A review. Journal of Polymers and the Environment, 19, 152-165. https://doi.org/10.1007/s10924-010-0258-0

Ramkissoon, H., \& Mavondo, F. (2014). Proenvironmental behavior: The link between place attachment and place satisfaction. Tourism Analysis, 19, 673-688. https://doi.org/10.3727/108354214X14146846679286

Ramkissoon, H., Weiler, B., \& Graham, L. (2012). Place attachment and pro-environmental behaviour in national parks: The development of a conceptual framework. Journal of Sustainable Tourism, 20, 257-276. https://doi.org/10.1080/09669582.2011.602194

Rath, J. M., Rubenstein, R. A., Curry, L. E., Shank, S. E., \& Cartwright, J. C. (2012). Cigarette litter: Smokers' attitudes and behavior. International Journal Environmental Resources Public Health, 9, 2189-2203. https://doi.org/10.3390/ijerph9062189

Raymond, C., Brown, G., \& Weber, D. (2010). The measurement of place attachment: Personal, community, and environmental connections. Journal of Environmental Psychology, 30, $422-434$. https://doi.org/10.1016/j.jenvp.2010.08.002

Reams, M. A., Geaghan, J. P., \& Gendron, R. C. (1996). The link between recycling and litter: A field study. Environment and Behavior, 28, 92-110. https://doi.org/10.1177/0013916596281005

Relph, E. (1976). Place and Placelessness, London: Pion.

Roberts, J. A. (1996). Green consumers in the 1990s: Profile and implications for advertising. Journal of Business Research, 36, 217-231. https://doi.org/10.1016/0148-2963(95)00150-6

Robertson, R. M., Thomas, W. C., Suthar, J. N., \& Brown, D. M. (2012). Accelerated degradation of cellulose acetate cigarette filters using controlled-release acid catalysis. Green Chemistry, 14, 2266-2272. https://doi.org/10.1039/C2GC16635F

Sapci, O., \& Considine, T. (2014). The link between environmental attitudes and energy consumption behavior. Journal of Behavioral and Experimental Economics, 52, 29-34. https://doi.org/10.1016/j.socec.2014.06.001

Schultz, P. W., Bator, R. J., Large, L. B., Bruni, C. M., \& Tabanico, J. J. (2013). Littering in context: Personal and environmental predictors of littering behavior. Environment \& Behavior, 45, 35-59. https://doi.org/10.1177/0013916511412179

Schultz, J., \& Oleen, B. (2014). States with littering penalties. Retrieved from http://www.ncsl.org/research/environment-and-natural-resources/states-with-littering-penalties.aspx

Schultz, P. W., \& Stein, S. R. (2009). Littering in America: National findings and recommendations (Executive Summary). Washington, DC: Keep America Beautiful.

Schwartz, S. H. (1977). Normative influences on altruism. Advances in experimental social psychology, 10, 221279. https://doi.org/10.1016/S0065-2601(08)60358-5

Solvay (2016). Cellulose acetate-an everyday bio based material with a century of history (2015). Solvay. Retrieved from http://www.solvay.com/en/binaries/Cellulose-Acetate_Brochure_en_low-170415.pdf.

Steg, L., \& Vlek, C. (2009). Encouraging pro-environmental behaviour: An integrative review and research agenda. Journal of Environmental Psychology, 29, 309-317. https://doi.org/10.1016/j.jenvp.2008.10.004

Tonge, J., Ryan, M., Moore, S., \& Beckley, L. (2014). The effect of place attachment on pro-environment behavioral intentions of visitors to coastal natural area tourist destinations. Journal of Travel Research, 54, 730-743. https://doi.org/10.1177/0047287514533010

Tourinho, P. S., do Sul, J. A. I., \& Fillmann, G. (2010). Is marine debris ingestion still a problem for the coastal marine biota of southern Brazil? Marine Pollution Bulletin, 60, 396-401. https://doi.org/10.1016/j.marpolbul.2009.10.013

Tseng, S. C., \& Hung, S. W. (2013). A framework identifying the gaps between customers' expectations and their perceptions in green products. Journal of Cleaner Production, 59, 174-184. https://doi.org/10.1016/j.jclepro.2013.06.050 
Tuan, Y. (1974). Topophilia. Englewood Cliffs, NJ: Prentice-Hall.

Tuan, Y. (1975). Place: An experiential perspective. The Geographical Review, 65, 151-165. https://www.jstor.org/stable/213970

Tudor, D., \& Williams, A. (2003). Public perception and opinion of visible beach aesthetic pollution: The utilisation of photography. Journal of Coastal Research, 19, 1104-1115. https://www.jstor.org/stable/4299252

University of Georgia. (2016). Marine debris tracker. Retrieved from http://www.marinedebris.engr.uga.edu/newmap/

Vaske, J. J., \& Kobrin, K. C. (2001). Place attachment and environmentally responsible behavior. The Journal of Environmental Education, 32, 16-21. https://doi.org/10.1080/00958960109598658

Vaz, B., Williams, A.T., Pereira, C., \& Phillips, M. (2009). The importance of users' perception for beach management. Journal of Coastal Research, 56, 1164-1168.

VERBI Software GmbH. (2015). Maxqda (12th edition)

Verplanken, B., \& Orbell, S. (2003). Reflections on past behavior: A self-report index of habit strength. Journal of Applied Social Psychology, 33, 1313-1330. https://doi.org/10.1111/j.1559-1816.2003.tb01951.x

Verplanken, B., \& Wood, W. (2006). Interventions to break and create consumer habits. Journal of Public Policy \& Marketing, 25, 90-103. https://doi.org/10.1509/jppm.25.1.90

Vining, J., \& Ebreo, A. (1992). Predicting recycling behavior from global and specific environmental attitudes and changes in recycling opportunities. Journal of Applied Social Psychology, 22(20), 1580-1607. https://doi.org/10.1111/j.1559-1816.1992.tb01758.x

Williams, D. R. (2000). Notes on measuring recreational place attachment. Unpublished Report Supplied by Dr. Dan Williams, Rocky Mountain Research Station, Ft. Collins, CO.

Williams, D. R., \& Vaske, J. J. (2003). The measurement of place attachment: Validity and generalizability of a psychometric approach. Forest Science, 49, 820-840. https://doi.org/10.1093/forestscience/49.6.830

\section{Copyrights}

Copyright for this article is retained by the author(s), with first publication rights granted to the journal.

This is an open-access article distributed under the terms and conditions of the Creative Commons Attribution license (http://creativecommons.org/licenses/by/4.0/). 